Diabetologia (1994) 37: 721-724

\title{
Non-linkage of the glucagon-like peptide 1 receptor gene with maturity onset diabetes of the young
}

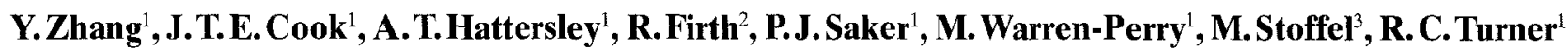 \\ ${ }^{1}$ Diabetes Research Laboratories, Radcliffe Infirmary, Oxford, UK \\ ${ }^{2}$ Mater Misericordiae Hospital, Endocrine Department, Dublin, Ireland \\ ${ }^{3}$ Howard Hughes Medical Institute and Department Medicine, The University of Chicago, Chicago, USA
}

\begin{abstract}
Summary Glucagon-like peptide-1 (GLP-1) is a hormone derived from the preproglucagon molecule that is secreted by intestinal L cells and stimulates insulin secretion from betacells. The GLP-1 receptor is a candidate gene for diabetes mellitus, as mutations may induce the impaired insulin response that is a characteristic feature of NIDDM. To study the relationship between the GLP-1 receptor gene and NIDDM, linkage of a microsatellite polymorphism flanking the GLP-1 receptor gene with diabetes was investigated in three Caucasian families with MODY and in the nuclear families of 12 NIDDM probands. A cumulative LOD score -8.50 excludes linkage in these MODY
\end{abstract}

pedigrees. A LOD score of -1.24 in the NIDDM nuclear pedigrees makes linkage improbable. Mutations in or near the GLP-1 receptor gene are unlikely to be the major cause of the inherited predisposition to NIDDM in Caucasian pedigrees, but we cannot exclude a role for this locus in a polygenic model or a major role in some pedigrees. [Diabetologia (1994) 37: 721-724]

Key words Glucagon-like peptide- 1 receptor, non-insulin-dependent diabetes mellitus, maturity onset diabetes of the young, polymerase chain reaction, linkage analysis.
Genetic predisposition to the development of NIDDM is indicated by concordance in monozygotic twins, familial aggregation and differences in prevalence between different populations. The major genes involved in the development of NIDDM have yet to be elucidated. NIDDM is characterised by peripheral insulin resistance, increased hepatic glucose efflux, and diminished secretion of insulin from pancreatic beta-cells [1]. GLP-1, a peptide derived from proglucagon, is secreted from the small intestine during a meal and after oral glucose administration [2]. It enhances glucose-de-

Received: 26 November 1993

and in revised form: 28 February 1994

Corresponding author: Dr. R. C. Turner, Diabetes Research Laboratories, Radcliffe Infirmary, Woodstock Road, Oxford OX2 $6 \mathrm{HE}, \mathrm{UK}$

Abbreviations: GLP-1, Glucagon-like peptide-1; NIDDM, noninsulin-dependent diabetes mellitus; MODY, maturity onset diabetes of the young; LOD, logarithm of the odds for linkage vs non-linkage; IGT, impaired glucose tolerance; bp, base pair. pendent insulin secretion both in vitro and in vivo. The GLP-1 receptor (GLP-1 R) has recently been characterised and is one of the distinct group of seven transmembrane-spanning G-protein coupled receptors [3] including receptors for secretin, parathyroid hormone, calcitonin, vasoactive intestinal peptide, growth hormone releasing hormone and glucagon. In a rat model of NIDDM, GLP-1 had an impaired stimulatory effect on glucose-induced insulin secretion [4]. In humans, an infusion of pharmacological doses of GLP-1 improves insulin secretion and increased glucose disposal in NIDDM patients. This suggests increased levels of GLP-1 can compensate for a defect in the glucose signalling pathway that regulates insulin secretion from betacells and may confer glucose sensitivity to glucoseresistant betacells. GLP-1 also has been proposed as a new therapeutic agent to stimulate insulin secretion by betacells of NIDDM patients [5,6].

As mutations in the GLP-1 receptor gene could contribute to impaired betacell function and development of diabetes, we have studied a DNA microsatellite, $(\mathrm{TG})_{\mathrm{n}}$ repeat polymorphism near the GLP-1 receptor 
(1)

(2)

(3)

(4)

II $\left.\sum_{1 / 4}^{1} \int_{1 / 2}^{1}\right|_{1 / 2} ^{3}$

$1 \bigcirc_{1 / 6}^{1} \overbrace{1 / 6}^{2}$

1) $\overbrace{4 / 7}^{1 / 4} \overbrace{4 / 7}^{2}$

(5)

$1 \sum_{6 / 6}^{\overbrace{5 / 6}^{1}} \int_{6 / 7}^{2}$

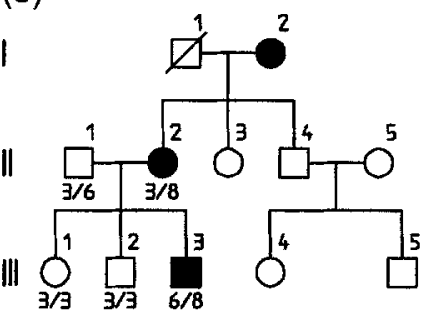

(6)

(7)

(8)

(9)

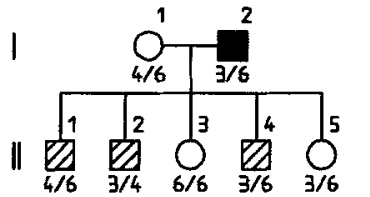

(10)

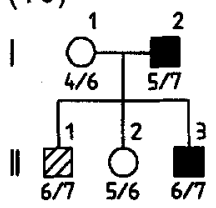

(11)

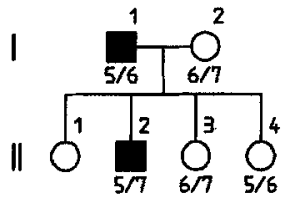

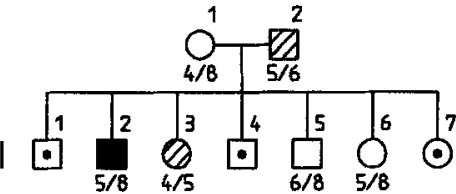

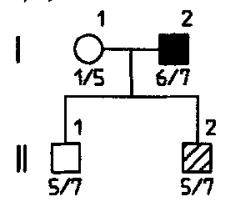

(12)

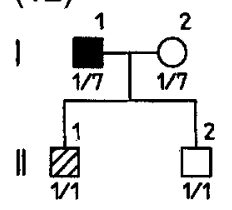

।

$\nabla+\varnothing^{2}$

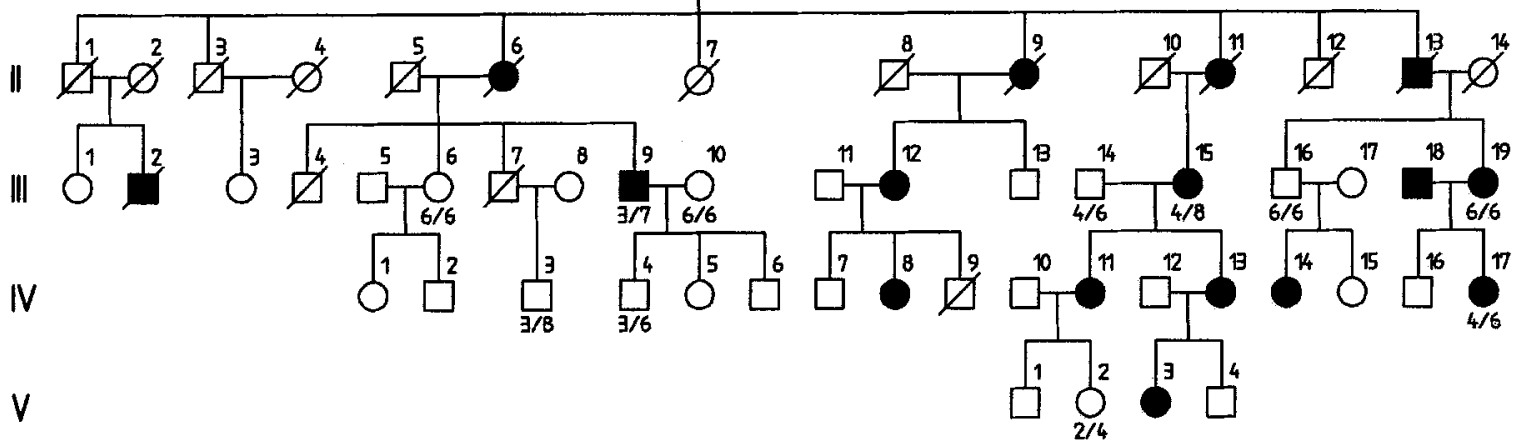

(14)
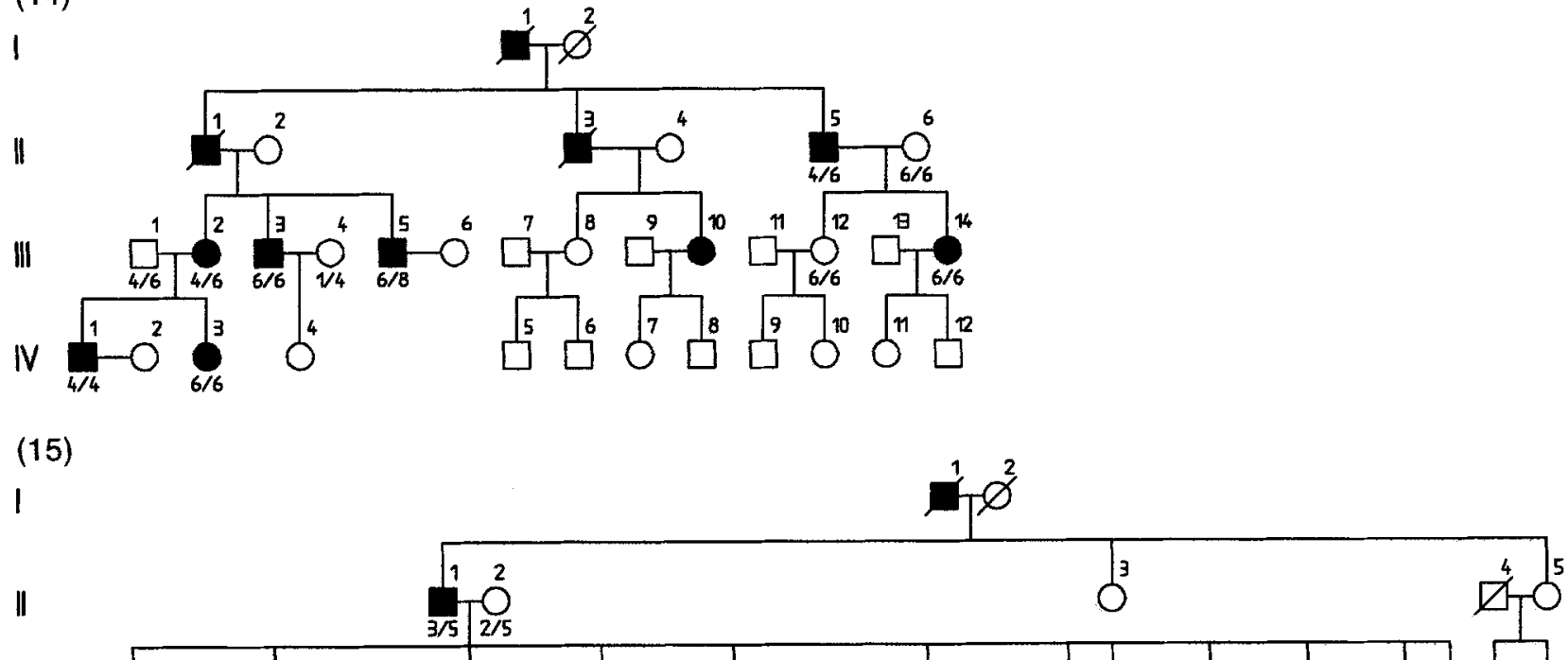

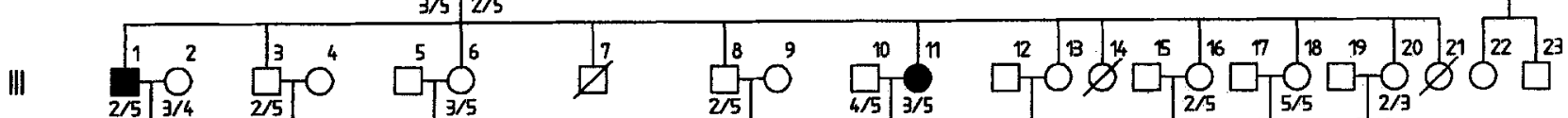

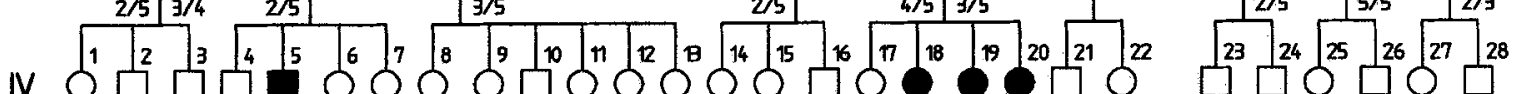

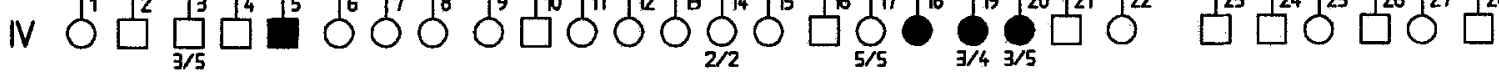


gene locus. Using polyacrylamide gel electrophoresis to separate the different alleles and a non-radioactive detection method, we studied the segregation of GLP$1 \mathrm{R}$ gene with diabetes in Caucasian pedigrees with MODY. We also studied Caucasian pedigrees with NIDDM.

\section{Subjects and methods}

Subjects. Three Caucasian MODY families and 12 unselected NIDDM Caucasian nuclear families were included in the analysis. These were from 14 nuclear families studied after exclusion of two pedigrees that were uninformative as the diabetic subject in the first generation was homozygous for the GLP-1 R polymorphism allele. The MODY families were from Oxford, London and Dublin; the 12 nuclear families from the Oxford area are shown in Figure 1. Segregation with the glucokinase gene had previously been excluded in these MODY families [7]. DNA was extracted from peripheral blood by using either the standard phenol/chloroform method or Nucleon II DNA extraction kit (Scotlab, Coatbridge, Lanarkshire, UK).

$P C R$ analysis. A polymorphic dinucleotide (TG) $)_{n}$ repeat element located close to human GLP-1 receptor gene on chromosome $6 \mathrm{p} 21$ was investigated [8]. Eight different alleles were observed using the PCR. DNA $(0.2 \mu \mathrm{g})$ was incubated with $0.1 \mathrm{U}$ heparinase and $50 \mathrm{mmol} / \mathrm{l} \mathrm{KCl}, 10 \mathrm{mmol} / 1$ Tris- $\mathrm{HCl}$, pH 8.3 buffer at $37^{\circ} \mathrm{C}$ for $1 \mathrm{~h}$. For PCR 10 pmol of oligonucleotides GLP1R-CA2 (5'-TCCTTGCTGCAGCCGGGTGG-3') and GLP1R-CA3 (5'-TACCTGTCTGATGGGTTTGG-3') were added to a $50-\mu \mathrm{l}$ reaction volume containing $200 \mu \mathrm{mol} / 1$ each of dATP, dCTP, dGTP, dTTP, $2.0 \mathrm{mmol} / 1 \mathrm{MgCl}_{2}$ and $1.5 \mathrm{U}$ of Taq Polymerase in a GeneAmp 9600 PCR System (Perkin-Elmer/Cetus, Norwalk, Conn., USA). The PCR was performed by initially denaturing for 5 min at $94^{\circ} \mathrm{C}$, followed by 30 cycles of denaturation at $94^{\circ} \mathrm{C}$ for $1 \mathrm{~min}$, annealing at $65^{\circ} \mathrm{C}$ for $30 \mathrm{~s}$ and extension at $72^{\circ} \mathrm{C}$ for $90 \mathrm{~s}$, with a final extension step for $10 \mathrm{~min}$ at $72^{\circ} \mathrm{C}$. One microgram of the PCR product was electrophoresed on a $8 \%$ polyacrylamide gel run at $130 \mathrm{~V}, 20^{\circ} \mathrm{C}$ for $16 \mathrm{~h}$, and bands were detected by ethidium bromide staining.

Linkage analysis. Each family was considered separately for linkage analysis performed with the software LINKAGE program (version 5.1) assuming dominant inheritance [9]. As a probe for a candidate gene was being examined, LOD scores were calculated with the recombination fraction theta equal to zero, as appropriate for a putative candidate gene. Subjects with IGT were considered as diabetic for the analysis. Age-related penetrance, calculated from studies of first degree relatives of NIDDM patients, was taken into account. Liability classes were based on prevalence studies of diabetes in the population and in pedigrees of NIDDM subjects. A co-dominant effect was assumed from the increased risk of diabetes in offspring when both

Fig. 1. Informative NIDDM pedigrees (1-12) and MODY pedigrees (13-15) showing the inheritance of GLP-1 R alleles. Roman numerals on the left of the pedigrees indicate generation number, and the numbers above the symbols indicate the subject's number within each pedigree. The GLP-1 R DNA polymorphism alleles are noted under the symbols. Squares, males; circles, females; closed symbol, diabetes; diagonal shading, glucose intolerance; open symbol, normoglycaemia; central dot, not tested; oblique, dead
Table 1. LOD scores for linkage of GLP-1 $\mathrm{R}$ with diabetes in MODY and NIDDM nuclear families

\begin{tabular}{lcc}
\hline & MODY & NIDDM \\
\hline & -2.59 & -0.50 \\
& -4.89 & -0.20 \\
& -1.02 & -0.39 \\
& & 0.20 \\
& & 0.29 \\
& & -1.30 \\
& & -0.02 \\
& & 0.28 \\
& & -0.39 \\
Total & & 0.50 \\
& & 0.00 \\
& & -0.10 \\
\end{tabular}

parents are affected. Four liability classes for NIDDM were defined on the basis of age (class $1,>60$ years; class 2,41 60 years; class $3,21-40$ years; class $4,<20$ years) and five for MODY (class 1 , > 50 years; class $2,41-50$ years; class $3,31-$ 40 years; class $4,21-30$ years, class $5,<20$ years). The penetrance factors for heterozygous and homozygous genotype used for NIDDM were: $0.90,0.75,0.35,0.05$ and $0.95,0.90,0.80,0.40$, respectively, for MODY were $0.99,0.95,0.90,0.80,0.60$ for heterozygosity and 1 for homozygosity at all ages. To accommodate for potential heterogeneity, phenocopy rates for each liability class were $0.05,0.01,0.001,0.0001$ for NIDDM and 0.03, 0.005, $0.001,0.001$, and 0.0001 for MODY.

\section{Results}

Figure 1 shows the GLP-1 R genotypes in the MODY and the NIDDM nuclear pedigrees. The (TG) $)_{n}$ polymorphism showed eight alleles with a size range from $134 \mathrm{bp}$ to $148 \mathrm{bp}, 2 \mathrm{bp}$ difference between each allele. The heterozygosity was $82 \%$ with 144 bp allele being the most prevalent at $28 \%$. The LOD scores at a recombination fraction of zero $(\theta=0)$ are shown in Table 1. The cumulative LOD scores were -8.50 for MODY families and -1.24 for the NIDDM nuclear families. These results were little affected by changing the penetrance and/or phenocopy rates by $+10 \%$ or $-10 \%$, the LOD score for the MODY families being in the range -9.44 to -6.71 and for NIDDM families -1.51 to -0.75 .

\section{Discussion}

Defects in insulin secretion are a common feature of NIDDM. Since glucagon-like peptide-1 plays an important role in modulating glucose-stimulated insulin secretion, and pharmacological levels of GLP-1 ameliorate the defect, mutations in the GLP-1 receptor are a candidate for the impaired beta-cell response. A cumulative LOD score of -8.50 at a recombination fraction of $\theta=0$ significantly rejected linkage of GLP-1 R 
in the large MODY pedigrees studies. With regard to the NIDDM nuclear pedigrees examined, a cumulative LOD score of -1.24 implies that linkage is unlikely, even though the cumulative LOD score did not reach the threshold of -2 generally considered to confirm non-linkage.

Linkage analysis in pedigrees is a powerful tool for examining the role of candidate genes in the aetiology of inherited diseases with a defined mode of transmission. Families with MODY are particularly suitable as they have clearly discernible autosomal dominant inheritance, the early age of onset allows ascertainment of affected members over three generations [10]. A major role for a candidate gene in NIDDM can be studied by examining several NIDDM pedigrees with due allowance for the high disease prevalence and late age of onset by age-dependent penetrance. The results indicate that mutations of the GLP-1 R gene are unlikely to have a major role in the pathogenesis of MODY or NIDDM, but do not exclude a role for GLP-1 receptor defects in a minority of NIDDM pedigrees.

Acknowledgements. We are grateful to Dr. G.I.Bell, Dr. W.O.C.M.Cookson, Dr. Y.-M.D.Lo, Dr. J. Davies, Dr. J.Levy, Ms. I.Stratton, Ms. B. Barrow and Mr. E. Bown for their advice and assistance. This study was supported by grants from the Alan and Babette Sainsbury Trust and Howard Hughes Medical Institute Foundation. We thank Ms. T. Summers for her assistance with the manuscript.

\section{References}

1. Unger RH, Foster DW (1992) Williams textbook of endocrinology. Saunders, Philadelphia, pp 1255-1333

2. Ørskov C (1992) Glucagon-like peptide-1, a new hormone of the entero-insular axis. Diabetologia 35: 701-711

3. Thorens B (1992) Expression cloning of the pancreatic betacell receptor for the gluco-incretin hormone glucagon-like peptide-1. Proc Natl Acad Sci USA 89: 8642-8645

4. Suzuki S, Kawai K, Ohashi S, Mukai H, Murayama Y, Yamashita K (1990) Reduced insulinotropic effects of glucagonlike peptide $1(7-36)$ amide and gastric inhibitory polypeptide in isolated perfused diabetic rat pancreas. Diabetes 39: $1320-1325$

5. Gutniak M, Ørskov C, Holst JJ, Ahrén B, Efendic S (1992) Antidiabetogenic effect of glucagon-like peptide-1 (7-36) amide in normal subjects and patients with diabetes mellitus. N Engl J Med 326: 1316-1322

6. Nauck MA, Kleine N, Ørskov C, Holst JJ, Willms B, Creutzfeldt W (1993) Normalization of fasting hyperglycaemia by exogenous glucagon-like peptide 1 (7-36 amide) in type 2 (non-insulin-dependent) diabetic patients. Diabetologia 36: 741-744

7. Hattersley AT, Turner RC, Permutt MA et al. (1992) Linkage of type 2 diabetes to the glucokinase gene. Lancet 339 : 1307-1310

8. Stoffel M, Espinosa R, Lebeau MM, Bell GI (1993) Human glucagon-like peptide receptor gene. Diabetes 42: 1215-1218

9. Lathrop GM, Laloud JM (1984) Easy calculation of LOD score and genetic risks on small computers. Am J Hum Genet 36:460-465

10. O'Rahilly S, Wainscoat JS, Turner RC(1988) Type 2 (non-insulin-dependent) diabetes. New genetics for old nightmares. Diabetologia 31: 407-414 